\section{E A Institute of \\ YK Business Administration \\ 光 \\ Karachi \\ Leadership and Ideas for Tomorrow}

\section{Business Review}

Volume 3 Issue 2 July-December 2008

$7-1-2008$

\title{
Front Matter of Volume 3 Number 2
}

Tufail A. Qureshi

Institute of Business Administration, Karachi, Pakistan

Follow this and additional works at: https://ir.iba.edu.pk/businessreview

Part of the Business Commons

c) (i)

This work is licensed under a Creative Commons Attribution 4.0 International License.

\section{Recommended Citation}

Qureshi, T. A. (2008). Front Matter of Volume 3 Number 2. Business Review, 3(2). Retrieved from https://doi.org/10.54784/1990-6587.1147

This article is brought to you by iRepository for open access under the Creative Commons Attribution 4.0 License and is available at https://ir.iba.edu.pk/businessreview/vol3/iss2/1. For more information, please contact irepository@iba.edu.pk. 


\title{
Business Review
}

\author{
IBA \\ 찾
}

RESEARCH JOURNAL of

THE INSTITUTE OF BUSINESS ADMINISTRATION KARACHI - PAKISTAN 


\title{
IBA \\ 掞 \\ $3 \sqrt{11}$ \\ Business Review
}

Editorial Board

Ishrat Husain

Director

Khadija Malik Bari

Talat A. Wazarat

Zeenat Ismail
Tufail A. Qureshi

Editor

\section{Advisory Board}

Toshio Fujita

Institute of Business Administration, Karachi, Pakistan

Javed Hussain

Mirza Sardar Hussain

Naved Ahmed

\section{External Editors}

\author{
Akif Hassan \\ IQRA University, Karachi, Pakistan \\ Abdul Rashid \\ International Islamic University, Islamabad, Pakistan
}

\section{Consulting Foreign Editors}

Deepak Kapur

Institute of Management Technology

Ghaziabad, UP, India

Low Sui Pheng

National University of Singapore

Singapore

S.W.S.B. Dasanayaka

University of Moratuwa

Sri Lanka

Faisal Manzoor Arain

Southern Alberta Institute of Technology

Canada
Arun Diwaker Nath Bajpai

Rani Durgavati University

Jabalpur, MP, India

Khurshid M.Kiani

Bang College of Business

Almaty, Republic of Kazakhstan

Bettina Robotka

Humbolt University Berlin

Germany

Khursheed Omer

University of Houston

Downtown Texas, USA 
https://ir.iba.edu.pk/businessreview/vol3/iss2/1

DOI: https://doi.org/10.54784/1990-6587.1147 


\section{O N T E N T S}

Editorial Perspective.

\section{Articles}

Post - Globalization Power Sector Management in India:

J.G. Valan Arasu, A.D.N. Bajpai, Shubhada Pandey

Capitalist Subjectivity, Capitalist Governance and the 'Anti-Globalisation' Movement:

Javed A. Ansari, Syed Zeeshan Arshad, Ali Muhammad Rizvi

Leveraging on Knowledge Management Approach for Effective Risk Management in Building Projects: Faisal Manzoor Arain

The Implementation of Trademark Law in Small and Medium Size Enterprises (SME)

Business Activities in Indonesia: Alexander Y Agung Nugroho, Sih Yuliana

Wahyuningtyas.

Brand Loyalty, Store Loyalty and Demographic Variables: Relational Study:

Zeenat Ismail.

\section{Discussions}

Consolidation in Indian Banking Industry - Need of the Hour:

Syed Ahsan Jamil, Bimal Jaiswal, Namita Nigam

Converged Service of Data, Video and Voice -Readiness of Pakistani Market:

Syed Irfan Nabi, Danish Akbar, Karim Chagani, Adnan Anwar Khan,

Anwar ul Haq.

The Influence of Culture on Advertising Effectiveness in Pakistan and Australia: A CrossCultural Study: Faiz Muhammad Shaikh.

\section{Case Studies}

Pilot Study of 8 SMEs in Pakistan: Ejaz Ahmed Mian

\section{News and Views}

$5^{\text {th }}$ European Symposium on Gender and ICT 2009

A Word About the IBA

About our Authors

Note for Contributors

Contents of Vol. 1, No. 1, Vol. 2, No. 1, Vol. 2, No. 2 and Vol. 3, No. 1 


\section{Editorial Perspective}

$\mathrm{T}$

he critics of corporate culture have given acute explications of the subtle flaws and limitations inherent in the corporate world-view. Their criticism derives its force from the two invariant qualities or the basic set of predicates - power and authority stipulated to define the corporate culture. Also, they have argued that our corporate functionaries are not necessarily veterans who have grown older and wiser in their professional fields of executive and managerial occupations. Their argument is based on the criteria that the level of intellectual development of a business executive becomes manifest in and through his human resource management and the way he conducts himself in his inter-personal relationships. The distinction that the critic is concerned with is of a general relevance in relation to the corporate culture and it is only one of the defining characteristics that can be correctly attributed to the functionaries of the corporate organizations. Some of his reasoning is spurious and not all of his thinking is reasoning. The distinction can be taken up and disposed of briefly as an example vitiated at best by the politics of corporate experience. For instance, given our situation and circumstances, it will be unrealistic to raise the expectations regarding the intellectual level of our corporate and political functionary to the height of Euripides who claimed to have found authority and "power in the mysteries of thought"

What is puzzling and peculiar about this argument is that it derives its force and takes its literal meaning from ethical and moral considerations, rather than the manifestations of intellect in the human context.

Surely, it is not true, the critics insist, that our corporate functionaries are an embodiment of moral and ethical virtues, but it ought to be. His argument also suggests that the life of a moral person is a witness to his struggle against inauthenticity; it is a testimony to his glorious victory over the painful anguish of self-defeat. It is a life free from blemish and debauchery, something that can hardly be said of our political leaders and corporate functionaries. Their's is not a morality touched by religion; it is pragmatism deepened by pure and pristine expediency. The line is drawn quite firmly and the sweep does not create any dilemmas for the corporate functionary. Blatant deviations and insidious sophistries are inflicted upon our intelligence in total abandon. Since we do not know on what ethical and moral grounds he will defend his position, he feels secure in the knowledge that we do not know how to counter his defense. The critic makes no secret of his reservations about the moral stature of our political and corporate functionaries. They are not under compulsion to incorporate into their lives intrinsic and cardinal virtues to merit the distinction of socio-cultural elitism. They are not an embodiment of Socratic refrain and virtue is not the other side of their knowledge. It is a dreary truth that we have come to accept. To some of us it will sound a harsh judgement. But, however biased and erroneous it may sound, it is a sad reality and it is always true, when it is not false. Perhaps so, but the critics have also inquired into the source of this benign 
confidence. They have traced it to the relationship between the corporate system and the corporate functionary.

What lends such inexorable meaning and significance to this gloomy phenomenon is the assumption that it is not by virtue of their ethical and moral grounding or the force of their character that our corporate executive permeate our business community and run our corporate system. Our corporate executive and business managers derive their sense of power and authority, both in the literal and metaphorical sense, from their willing subservience to the status quo and the uncritical acceptance of the "given" and the taken for granted sacrosanct assumptions of the corporate system. By training, they are programmed into a mind set which is conducive to the unreflective attitude because it takes away the anxiety suffered by an inquiring mind pursuing a vision driven evaluative and normative model of corporate organization and business management. By creating a carefully contrived alternate reality, the corporate system replaces the functionary's ideology with the official corporate ideology. It gives our corporate executives the luxury to relish certainty and confidence enjoyed by the one dimensional man. Such a captive mind, culturally domesticated to the ideology of the corporate system and by virtue of his willing subservience to it, enjoys the power to neutralize or rationalize cognitive dissonance, inward dissent and moral anxiety. Also, by means of such mechanisms, corporate system focuses on outward behaviour and discourages inward look. It emphasizes behavioural disposition which forbids reflexive consciousness. However, reflexive awareness and inward disposition are the fundamental ethical and psychological requirements for a healthy socio-cultural development. In a corporate paradigm, possibilities of such inclinations and the development of subjectively nurtured dispositions are considered dangerous prospects. That is because, with the provision of social and cultural contact, they tend to undermine the power and authority enjoyed by the functionary of a corporate organization by virtue of his subservience to the status quo. Placed in the domain of governance and decision making, such tendencies and inclinations land the serious business of management grater depth and relevance. Ironically, they become more and more deeply rooted in the corporate reality out of which they emerge and simultaneously and progressively tend to become a comment and critical evaluation of that "given" reality. Paradoxically, by its curious mechanisms, the corporate system generates its own inherent contradictions, conflicts and tensions which can lead to the total collapse of its paradigm. It is a vicious circle and the situation is not too different with the noncorporate organizations.

A corporate system, like any other system, is designed to manage human affairs. It is subject to its own inner laws which determine the formal structures of the ways and the means of conducting these affairs. Within the fabric of the corporate system, its evaluative judgements and decision making lie the workings of power and authority. These hard qualities, woven into the texture of the corporate culture, determine the nature of the relationship of the corporate functionary to the corporate ideology. The managerial and executive responsibilities of the corporate 
functionaries constitute a cobweb of relations, defining the nature of the evaluative judgements regarding their relationship to the so called "objective facts" about the corporate reality. Here the teleological consideration is based not so much upon what the relationship is but how the existing relationship is experienced. Reality, notwithstanding corporate reality, is always given in and through experience because through what else could it be given? Since all experience is interpreted experience, it is by nature the experience of something $a s$ it is experienced by the experiencing subject. Such a phenomenological understanding of the corporate reality lends meaning and significance to the organization in which our corporate functionaries exercise their vested power and authority, as the defining metaphors of corporate culture, having an all pervasive influence and affecting practically everything in the domain of corporate organization. Moreover, as we look deeper into the genesis of power and authority, we come to realize that the workings of power and authority are not confined to the administrative and managerial aspects of the corporate reality; there is also a socio-cultural side to these defining concepts which becomes manifest as they are mediated in and through the personality structure of the functionaries of the corporate society. Power and authority, as extensions of thought and action define the formal structures of the corporate reality as it is intended and constituted by the corporate functionaries with reference to the ideology of the corporate system. Such an ideology can be a sublime vision of the world to be, but it can also be a symptom of a distorted and twisted world-view.

It shows that the complex workings of a corporate system are deeply entwined with the psychological and ethical dimensions of the personality and character of the functionary of the corporate system. In a humanistic world-view, characterized by a dynamic and transcending vision, this relationship is premised upon the requirement of how to use our ethical and moral edge to our advantage in the management of corporate affairs. The thought here is that a normative approach and a transcending vision will play an empowering creative role in the construction and reconstruction of the corporate world as it is into a world as it ought to be. As we engage in the management of our corporate affairs, we realize that the matters pertaining to the corporate world belong to the most stubborn structure of human condition. By their inherent dialectic, these matters endure all attempts at falsification and denial. Examined against the paradigm of the lived-world, corporate reality, as lived-reality, by its inherent logic, is self-evident and apodictic. It also shows that the domain of lived-reality is the sphere where only he who knows the truth can tell a lie. For all intent and purposes, for all practical and pragmatic reasons, we are compelled to call the world, as John Keats did, the "vale of soulmaking". It will be quite appropriate then to call the will and the power as metaphors of divine lure, prompting us to make and remake the world, or, in a much more analytic way, the essential components of a world-view representing the fusion of the world as it is and the world as it ought to be.

Thus in the same vein of thought, the world that really deserve that name is the lived-world. "The world" is a vacuous concept and the world per se does not 
exist. Only the worlds exist - your's and mine, our's and their's, idealistic and materialistic, secular and sacred, just and unjust, rational and absurd. Moreover, at any given stage of its development, the world does not exist in its finished form; it is a constantly changing world, always incomplete always to be continuously made and remade. In such a world, nothing is permanent and everything is subject to the law of becoming. Again, at any given stage of its development, the 'given' world represents the drama of unfolding horizon and perspective, always moving towards the world to be. We may even venture to suggest that the world is a place where creative will as moral power is to be tested to the limit of our transcending vision. To be more specific, by moral power we mean "the power of life and a character, the power of good and great purposes, the power which comes at length to reside in a man distinguished in some course of estimable or great conduct. No other power of man compares with this, and there is no individual who may not be measurably invested with it." (Horace Bushnell)

So, in short, moral power issues from the will to power which is the will to truth and the will to truth is the will to transcend. It is the invincible power indistinguishable from man's character. The admonition Plutarch uttered long time ago is a refrain full of wisdom even in its present tense meaning. "It is an observation", he is known to have said, "no less just than common, that there is no stronger test of a man's real character than power and authority, exciting as they do every passion, and discovering every latent vice."

Several centuries ago, Socrates who could see the advent of nihilism looming large over the horizon of his age, identified knowledge with virtue. It is so remarkable that what he held to be true of his situation should be true and perhaps more so of our age which has witnessed a systematic denial and destruction of normative values. Seven hundred years ago, Roger Bacon, like us, lamented the neglect of moral philosophy by the scholars of his age. And again, it is so remarkable that what Hazrat Ali said about his time should be such a powerful indictment of our age. In his words, "we are passing through times when majority of worldly people think that hypocrisy means wisdom and they lead the uneducated masses to believe dissimulation is the best form of sagacity."

No one can deny the importance of specialization and departmental training in the modern system of education. However, denouncing the extent to which specialized vocational training has displaced humanistic studies in our educational institutions, particularly in the institutions of business education, William H. Whyte, Jr., in The Organization Man, wrote:

"It is not entirely facetious to suggest that the only way any reform could be effected would be through a subversive movement by the humanist. In what would be poetic justice to the vocationalists, humanist in disguise would appropriate their terminology and smuggle education into the curriculum by pretending to specialize it further. Who would dare cavil at the humanities were they presented as "Mercantile Influence in the Renaissance", "Market Patterns in Pre-Industrial England", "Communication Techniques in Elizabethan Drama"? 
However, just to sprinkle, here and there, corporate thinking with ethical and moral anxieties, poetic metaphors, religious yearnings, cultural aspirations and psychological insights will not do. More, much more, needs to be done to help incorporate these strands into a self sustaining dynamic corporate world-view. It calls for a wide spectrum of collaborative research, creative vitality and vision oriented pedagogical bias.

Dispensation of poetic justice envisioned by William $\mathrm{H}$. Whyte, Jr. sounds a very desirable pedagogical strategy. Nevertheless, it is a task which can only be accomplished through concerted inter-disciplinary research. But, if we feel secure and satisfied in the awareness of what we know, unwilling and reluctant to understand what we do not know, we will have then defeated the teleological purpose of education. Sadly, ours is a society characterized by the loss of transcending vision. We are encumbered by petrifying desire, ruthless ambition, lust for power and authority, cognitive dissonance and lack of creative discontent. And yet, our's is not a lost case to deserve the self inflicted pity and contempt. So long as the high hope lingers on and our eyes with far away look stray to the distant horizons, so long as our creative will is not weary and we have the will and the power to shatter the "given" world, including the corporate "world", into pieces to make it many times over into a world of our unfulfilled desire, we can still hope to become what we are capable of becoming.

The truth lies out there but the real foe resides within. It is the danger posed by retrogressive ideology fettered to the past, lying in wait to contemporize once again what "used to be".

Here is a real scenario of eternal recurrence of the nemesis and the predicament inherent in human condition.

"The morning freshness of the world-to-be intoxicated us. We were wrought up with ideas inexpressible and vaporous but to be fought for. We lived many lives in those whirling campaigns, never sparing ourselves: yet when we achieved and the new world dawned, the old men came out again and took our victory to remake in the likeness of the former world they knew".

T.E. Lawrence: Seven Pillars of Wisdom. 
https://ir.iba.edu.pk/businessreview/vol3/iss2/1

DOI: https://doi.org/10.54784/1990-6587.1147

Business Review - Volume 3 Number 2

July - December 2008 